\title{
Mengajarkan Shalat Pada Anak Usia Dini Dalam Masa Social Distancing Covid-19 Perspektif Hadis
}

(Teaching Prayers to Early Children in the Covid-19 Social Distancing Period - the Perspective of Hadiths)

\author{
Nisaul Jannah, Muhammad Alfatih Suryadilaga \\ Universitas Islam Negeri Sunan Kalijaga, Yogyakarta, Indonesia \\ niisaauljannah@gmail.com
}

DOI: $10.29240 /$ alquds.v4i2.1638

Submitted: 2019-06-07 | Revised: 2020-08-21 | Accepted: 2020-09-07

\begin{abstract}
Teaching prayers to children is parents' and educators' obligation that must be done as early as possible. By teaching prayers since an early age, it is hoped that children can develop optimally in terms of physical, spiritual, and intellectual aspects, so that they grow into a generation with character. With the current outbreak of Covid19, the education and teaching processesare experiencing a number of obstacles because children cannot interact directly with people other than their parents. This article aimed to describe how to teach prayers to early children based on the guidance of the Prophet Muhammad's hadiths, especially during the social distancing period of Covid-19. The research in this article used a qualitative method with a descriptive analysis approach taken from a variety of document data and in-depth observations. The research revealed that teaching prayers to early children based on the Prophet Muhammad's hadiths deployed exemplary methods, habituation, advice, attention and monitoring, and punishment. Last but not least, parents and educators also provided educational materials such as religious, social, physical, moral and intellectual education.
\end{abstract}

Keywords: Prayers, early children, hadiths

Abstrak. Mengajarkan shalat kepada anak merupakan kewajiban orangtua dan para pendidik yang mesti dilakukan sedini mungkin. Dengan mengajarkannya sedari dini, diharapkan agar anak dapat berkembang maksimal, baik jasmani, rohani, maupun akalnya, sehingga tumbuh menjadi generasi yang berkarakter. Mewabahnya Covid-19 pada masa sekarang ini, proses pendidikan dan pengajaran mengalami sedikit kendala, karena anak-anak tidak dapat berinteraksi secara langsung dengan orang lain selain orangtuanya. Artikel ini bertujuan mendeskripsikan tentang bagaimana cara mengajarkan shalat kepada anak usia dini berdasarkan petunjuk hadis Nabi Muhammad SAW khususnya pada masa social distancing Covid-19. Penelitian dalam artikel ini menggunakan metode kualitatif dengan pendekatan analisis deskriptif yang diambil dari beragam data dokumen dan pengamatan mendalam. Penelitian dalam artikel ini 
menghasilkan bahwa dalam mengajarkan shalat kepada anak usia dini berdasarkan hadis Nabi Muhammad SAW adalah dengan menggunakan metode keteladanan, pembiasaan, nasihat, perhatian dan pemantauan, serta hukuman. Dan yang tidak kalah penting ialah orang tua serta pendidik juga memberikan materi pendidikan seperti pendidikan agama, sosial, jasmani, moral dan akal.

Kata Kunci: Shalat, anak usia dini, hadis

\section{Pendahuluan}

Artikel ini akan menjelaskan tentang bagaiamana pentingnya mendidik dan mengajarkan shalat pada anak usia dini di tengah-tengah social distanding di Indonesia.Untuk saat ini, seluruh dunia sedang dilanda dan ditakuti oleh wabah penyakit yang menular yaitu COVID-19 yang sebelumnya terjadi di Wuhan Tiongkok pada Desember 2019 lalu. Corona virus adalah suatu kelompok virus yang dapat menyebabkan infeksi saluran pernapasan pada manusia.Oleh sebab itu, seluruh warga negara dianjurkan oleh pemerintah untuk tetap menjaga batasan dalam bersosialisasi atau disebut juga social distancing yang tentunya sangat menghambat aktivitas semua warga negara seperti menutup tempat rekreasi, pembatasan dalam berbelanja bahan pokok, termasuk dalam hal pendidikan. Social distancing akan membantu mengurangi penularan COVID-19. Oleh karena itu, semua sekolah ditutup sampai kondisi normal kembali. Walau demikian, orang tua yang memiliki anak-anak yang masih menjalankan proses pendidikan dasar wajib belajar 9 tahun dan termasuk salah satunya Pendidikan Anak Usia Dini, maka orang tua wajib membimbingnya dengan maksimal.

Selama masa social distancing, orang tua bisa melakukan pendidikan kepada anaknya seperti pendidikan agama dan moral khususnya mengajarkan shalat.Apa itu shalat, bagaimana gerakan shalat, bagaimana tata cara shalat, bagaimana tata cara bersuci, apa saja yang membatalkan wudhu, dan lain sebagainya. Anak usia dini adalah anak yang rentang usianya dari 0-6 tahun, yang mana ia masih berada dalam tahap golden age. Pada masa ini anak-anak akan mengalami kemudahan dan kelancaran dalam memahami ilmu baru yang didapatkannya. Oleh kerena itu, orang tua hendaknya mengajarkan shalat kepada anaknya sejak usia dini agar menjadi sebuah kebiasaannya beribadah ketika ia sudah dewasa kelak. Agar lebih jelasnya lagi, pemateri akan membahas tentang mengajarkan shalat kepada anak usia dini dalam social distancing covid-19 perspektif hadis.

Anak merupakan titipan Allah yang sangat berharga. Karena itu, orang tua dituntut untuk mendidiknya sejak masih dalam kandungan ibunya sampai dewasa, sebab setiap anak yang baru lahir selalu dalam keadaan suci. Maka saat kembali kepada Allah SWT nanti haruslah dalam keadaan suci, tanpa noda dan dosa. Karena itulah pendidikan terhadap anak dalam pandangan Islam adalah 
wajib. ${ }^{1}$ Terutama pendidikan agama dan moral. Di dalam hadist Bukhari, Ibnu Habban dan Baihaqqi menjelaskan bahwasannya orang tua sangat penting dalam perkembangan agama dan moral anak.Sebagai orang tua atau pendidik, kita sadar bahwa lingkungan yang paling bertanggung jawab terhadap pendidikan adalah keluarga, di samping lingkungan sekolah dan masyarakat. ${ }^{2}$ Keluarga ataupun orang tua merupakan pendidikan yang utama pada saat ini dalam siklus kehidupan masa pandemi Covid-19 di Indonesia saat ini. Maka penting bagi orang tua untuk mendampingi dan menanamkan pendidikan agama dan moral kepada anak usia dini di tengah-tengah masa pandemi Covid19 di Indonesia. Pada usia ini juga diharapkan orangtua dapat menjadi panutan yang baik bagi anak, karena pada masa pandemi Covid-19 waktu anak lebih banyak bersama orangtuanya. Sehingga semua yang orangtua lakukan, secara tidak langsung akan ditirukan oleh anak. Karena sejatinya anak merupakan peniru yang baik. Oleh karena itu, pendidikan agama dan moral penting untuk membantu anak dalam memasuki tahap selanjutnya.

Dalam mengoptimalkan perkembangan anak, orang tua perlu memberikan stimulus secara berkesinambungan. Karena anak masih dalam masa emasnya atau golden age.Pada masa ini, perlu ditanamkan pendidikan terutama pendidikan agama. Dan yang menjadi kewajiban setiap orang tua dalam menanamkan pendidikan gama dalah shalat. Karena dengan shalat, anak dapat belajar berkonsentrasi, disiplin, khusyu' dan bersabar selama melaksanakannya. Oleh karena itu, shalat harus dilatih sejak dini agar menjadi kebiasaan di waktu ia dewasa kelak.

Menyuruh anak sebagai anggota keluarga untuk melaksasnakan shalat merupakan kewajiban bagi orang tua.Perintah Allah kepada orang tua untuk memerintahkan anaknya shalat tidaklah mudah, sederhana, sekedar memerintah dan memerlukan waktu yang pendek. Di dalamnya tersirat banyak perintah yang lainnya yang berkaitan dengan proses pendidikan anak yang tidak luput dari tantangan dan rintangan serta membutuhkan waktu yang panjang. Seperti yang telah dijelaskan dalam [Q.S. Thaahaa (20) : 132)] yang artinya: "Dan perintabkanlah kepada keluargamu mendirikan Shalat dan bersabarlah kamu dalam mengerjakannya.Kami tidak meminta rezeki kepadamu, Kamilah yang memberi rezeki kepadamu.Dan akibat (yang baik) itu adalah yang bertaqwa."

\section{Literature Riview}

${ }^{1}$ Abdul Mua'thi Musthafa, Mengajari Anak Sholat. (Bandung: Irsyad Baitus Salam Diana Mutiah, 2012), 15.

2 Abdul Mustaqim, Quranic Pparenting, (Sleman: Lintang Hyuning Buwana, 2019), 48. 
Kajian tentang pembelajaran shalat pada anak usia dini merupakan hal yang penting di ajarkan dalam lingkungan keluarga sejak anak berusia 7 tahun. ${ }^{3}$ Walaupun belum menjadi kewajibannya untuk melaksanakan shalat. Namun, saaat anak mulai benjak usia 10 tahun, maka sudah menjadi kebiasaan dan menjadi kewajibannya dalam melaksanakan shalat. Dan apabila anak meninggalkan shalat, maka pukullah anak dengan pukulan mendidik yang tidak melukainya sesuai dengan hadis Nabi. Selama mengajarkan shalat, hendaknya orang tua memperhatikan tingkat perkembangan anak, sehingga anak mampu memahami secara optimal.

Kajian hadis dan mengajarkan shalat pada anak usia dini merupakan hal yang penting. Kajian tersebut dapat dilihat bahwa shalat merupakan tanggung jawab orang tua terhadap anak-anaknya, harus direalisasikan secepatnya dan secara optimal dimulai sejak anak lahir (dalam usia dini) dan harus dilandaskan dengan landasan iman yang sempurna dan akhlak yang benar, syariat dan moral Islami, sekaligus akhlak yang utama. ${ }^{4}$ Kajian tersebut dapat dilihat bahwa kajian selama ini masih dalam perspektif umum atau orang dewasa seperti kajian atas di daerah Pakistan, Indonesia melalui Pancasila, dan kaitan agama dan isu-isu ekonomi dan keagamaan. ${ }^{5}$ Padahal ajaran agama dan moral sangat penting bagi semua golongan usia termasuk di kalangan PIAUD. Kajian atas pentingnya tersebut masih belum banyak ditemukan bahkan nyaris tidak ditemukan. Beragam kekerasan atas anak menjadi bagian yang tak terelakkan dan terjadi di kalangan tersebut. Moral tersebut apalagi dikaitkan dengan Covid-19 yang merupakan musibah yang sangat erat dengan anak-anak yang memiliki dampak sosial khusunya bagi korban. ${ }^{6}$

${ }^{3}$ Risdianto Hermawan, Pengajaran Sholat pada Anak Usia Dini Perspektif Hadis Nabi Mubammad SAW, Vol. 23, No. 2, Juli-Desember 2018, 9.

4 "Arifah Budhyaty, M. Z. STRATEGI PENANAMAN NILAI-NILAI PENDIDIKAN ISLAM (Kajian Terhadap Perintah Shalat Dalam Hadis Riwa,” n.d.

${ }^{5}$ Anushka Ataullahjan, Zubia Mumtaz, and Helen Vallianatos, "Family Planning, Islam and Sin: Understandings of Moral Actions in Khyber Pakhtunkhwa, Pakistan," Social Science \& Medicine 230 (June 1, 2019): 49-56, https://doi.org/10.1016/j.socscimed.2019.03.011; Isadora Kirchmaier, Jens Prüfer, and Stefan T. Trautmann, "Religion, Moral Attitudes and Economic Behavior," Journal of Economic Behavior \& Organization 148 (April 1, 2018): 282-300, https://doi.org/10.1016/j.jebo.2018.02.022; S. Nishimura, "The Development of Pancasila Moral Education in Indonesia," Southeast Asian Studies (Kyoto) 33, no. 3 (1995): 303-16.

'Imran Ali and Omar M.L. Alharbi, "COVID-19: Disease, Management, Treatment, and Social Impact," Science of The Total Environment 728 (August 1, 2020): 19, https://doi.org/10.1016/j.scitotenv.2020.138861; Mohsen Ansari and Saeedeh Ahmadi Yousefabad, "Potential Threats of COVID-19 On Quarantined Families," Public Health, April 21, 2020, 19, https://doi.org/10.1016/j.puhe.2020.04.014; Ramdas Ransing et al., "Early Career Psychiatrists' Perspectives on the Mental Health Impact and Care of the COVID-19 Pandemic across the World," Asian Journal of Psychiatry, April 14, 2020, 19, https://doi.org/10.1016/j.ajp.2020.102085. 
Kajian Hadis dan PIAUD masih jarang ditemukan dalam kajian ilmiah lewat jurnal maupun penelitian secara khusus.Kenyuataan tersebut menjadikan penelitian atas PIAUD lebih pada kajian konsep pola PIAUD atas kemandirian siswanya dan kompetensi gurunya. ${ }^{7}$ PIAUD dalam konteks teoritis baik pemikirna tokoh tertentu, maupun telaah konseptual PIAUD dengan beragam isu kemoderenan sepertri gender dan dalam konteks keluarga. ${ }^{8}$ Secara spesifik kajian PIAUD atas kajian keilmuan dalam ajaran Islam ${ }^{9}$ Kajian umum lainnya dalam hadis kaitannya PIAUD adalah tentang urgensi pembelajaran hadis bagi Anak Usia Dini. ${ }^{10}$ Sehingga sepsifikasi kajian PIAUD akan lebih maksimal dalam konteks spesifik seperti kajian hadis dan materi yang cocok bagi mereka.

Kajian hadis sebagai sebuah bagian dari kerja akademik merupakan sesuatu hal yang berkembang dalam sejarahnya.Hadis tidak saja dikaji di pesantren ${ }^{11}$ di mana sebelum lahirnya $\mathrm{PT},{ }^{12}$ lembaga inilah yang mampu

${ }^{7}$ Mohammad Nurul Huda, "Strategi Mengajar Guru Dalam Meningkatkan Sikap Kemandirian Siswa Di PIAUD," Ta'dibi: Jurnal Manajemen Pendidikan Islam 7, no. 1 (September 3, 2018): 49-76; Nina Puspitaloka and Yuna Tresna Wahyuna, "Kesulitan-Kesulitan Yang Dihadapi Mahasiswa PIAUD Dalam Pembelajaran Bahasa Inggris," AWLADY: Jurnal Pendidikan Anak 4, no. 2 (September 30, 2018): 120-36, https://doi.org/10.24235/awlady.v4i2.3071; Laily Hidayati, "Qashashul Quran: Pengembangan Mata Kuliah Wajib Program Studi Pendidikan Islam Anak Usia Dini (PIAUD)," Proceedings of Annual Conference for Muslim Scholars, no. Seri 2 (May 14, 2017): 909-19.

${ }^{8}$ Safrudin Aziz, "Pendidikan Spiritual Berbasis Sufistik Bagi Anak Usia Dini Dalam

Keluarga," Dialogia 15, no. 1 June 1, 2017): 131-49, https://doi.org/10.21154/dialogia.v15i1.1188; Muhibuddin Fadhli, "Pemikiran Howard Gardner Dalam Pendidikan Anak Usia Dini," JURNAL INDRIA (Jurnal Ilmiah Pendidikan Prasekolah dan Sekolah Awal) 1, no. 1 (December 1, 2016), https://doi.org/10.24269/jin.v1n1.2016.pp69-80; Agus Purnomo, "Pendidikan Anak Dini Usia (PAADU) Dalam Islam: Sebuah Analisis Gender," EGALITA 0, no. 0 (May 12, 2012), https://doi.org/10.18860/egalita.v0i0.1965; Roziqoh Roziqoh and Suparno Suparno, "Pendidikan Berperspektif Gender Pada Anak Usia Dini," JPPM (Jurnal Pendidikan Dan Pemberdayaan Masyarakat) 1, no. 1 (March 1, 2014): 86-100, https://doi.org/10.21831/jppm.v1i1.2359; Wulandari Retnaningrum, "Pendidikan Karakter Bagi Anak Usia Dini Perspektif Islam,” Jurnal Warna 2, no. 2 (2018): 56-68.

9 Jumrah Jumrah, "Developing an Intensive Course Model in Improving English Language Skills of Students of Early Childhood Islamic Education Department (Piaud)," International Journal of Language Education 1, no. 1 (March 5, 2019): 22-32, https://doi.org/10.26858/ijole.v1i1.7435.

${ }^{10}$ Udzlifatul Chasanah, "Urgensi Pendidikan Hadis Dalam Pembentukan Karakter Anak Usia Dini," Jurnal Living Hadis 2, no. 1 (May 18, 2017): 83-115, https://doi.org/10.14421/livinghadis.2017.1357.

${ }^{11}$ Mochamad Samsukadi, "Paradigma Studi Hadis di Dunia Pesantren," Religi: Jurnal Studi Islam 6, no. 1 (April 10, 2015): 46-75.

${ }^{12}$ Muhammad Alfatih Suryadilaga, "Profil Prodi Ilmu Hadis Di Era Globalisasi Teknologi Informasi,” February 2, 2018, https://doi.org/10.21043/riwayah.v2i1.1502. 
mengkaji hadis melalui pendidikan non formal di dalamnya dan perkembangan berikutnya juga dalam pendidikan formal.Selain itu, kajian hadis juga ditemukan di Perguruan Tinggi yang memiliki sepesifikasi pada kajian khusus hadis seperti yang terjadi di Prodi Ilmu Hadis (ILHA) di PTKI. ${ }^{13}$ Kajian hadis terus berkembang menjadi bagian dari pendidikan seperti kajian hadis pada madrasah seperti Madrasah Ibtidaiyah, Tsanawiyah dan Aliyah. ${ }^{14}$ Kajian tersebut kemudian ditelaah kualitasnya oleh beberapa peneliti. ${ }^{15}$ Kajian hadis di dalamnya masih terbatas dalam satu mata pelajaran Qur'an Hadis. ${ }^{16}$ Kajian di pesantren juga ditemukan yakni di Ma’had Ály Tebuireng sebagaimana di dalamnya yang fokus kajian hadis. ${ }^{17}$

Kajian di atas menunjukkan bahwa banyak ragam kajian atas hadis yang berkembang dengan beragam ranah di dalamnya.PIAUD sebagai bagian ranah pendidikan melahirkan lembaga pendidikan khusus di PT di mana mereka yang ikut serta di dalamnya memilih prodi PIAUD lebih banyak perempuan. ${ }^{18} \mathrm{Hal}$ ini memacu kajian lebih mendalam atas beragam kajian dengan beragam keilmuan di dalamnya termasuk hadis.Kajian hadis dalam PIAUD masih langka dan belum menunjukkan perkembangan yang signifikan, maka kajian dalam artikel

${ }^{13}$ Muhammad Alfatih Suryadilaga, "Ragam Studi Hadis Di PTKIN Indonesia Dan Karakteristiknya: Studi Atas Kurikulum IAIN Bukittinggi, IAIN Batusangkar, UIN Sunan Kalijaga, Dan IAIN Jember," JOURNAL OF QUR'AN AND HADITH STUDIES 4, no. 2 (December 20, 2015): 215-47, https://doi.org/10.1548/quhas.v4i2.2394.

${ }_{14}$ St Nomah Ali, "Problematika Pembelajaran Al-Qur'an Hadis Di Madrasah Tsanawiyah Negeri (MTs.N) 1 Kolaka," Zawiyah: Jurnal Pemikiran Islam 4, no. 2 (December 28, 2018): 127-44, https://doi.org/10.31332/zjpi.v4i2.1082; M Niaz Asadullah and Nazmul Chaudhury, "To Madrasahs or Not to Madrasahs: The Question and Correlates of Enrolment in Islamic Schools in Bangladesh," International Journal of Educational Development 49 (July 1, 2016): 55-69, https://doi.org/10.1016/j.ijedudev.2016.01.005; Hasbiyallah Hasbiyallah, "Relevansi Materi Hadis Pada Jurusan Pai Dengan Bahan Ajar Quran Hadis Pada Madrasah Tsanawiyah," Atthulab: Islamic Religion Teaching and Learning Journal 1, no. 1 (February 17, 2016): 71-84, https://doi.org/10.15575/ath.v1i1.2436; Zailani dan Zumarni, "Studi Analisis Terhadap HadisHadis dalam Buku Paket Pada Sekolah Negeri dan Madrasah di Kota Pekanbaru," An-Nida' 39, no. 2 (February 5, 2014): 232-48; Ainul Yaqin, "Problematika Pembelajaran Al-Qur'an Hadis Di Madrasah Tsanawiyah Negeri (MTs.N) 1 Kolaka," Jurnal Kariman 2, no. 1 (2014): 69-84.

15Zumarni, "Studi Analisis Terhadap Hadis-Hadis dalam Buku Paket Pada Sekolah Negeri dan Madrasah di Kota Pekanbaru."

16.Wajidi Sayadi, "Hadis Daif Dan Palsu Dalam Buku Pelajaran Al-Qur'an Hadis Di Madrasah," Jurnal Analisa Balai Diklat Semarang 19, no. 02 (2012).

${ }_{17}$ Muhammad Alfatih Suryadilaga, "Dinamika Studi Hadis di PP Hasyim Asy'ari Tebuireng Jombang: Dari Klasikal Hingga Ma'had 'Aly," AL QUDS : Jurnal Studi Alquran dan Hadis 3, no. 2 (November 25, 2019): 119-34, https://doi.org/10.29240/alquds.v3i2.1001.

${ }^{18}$ Binti Su'aidah Hanur and Fatimah Fatimah, "Dari Pesantren Untuk PIAUD," Proceedings of Annual Conference for Muslim Scholars, no. Seri 2 (May 14, 2017): 898-908; Imas Masitoh, "Analisis Faktor-Faktor Yang Mempengaruhi Mahasiswa Memilih Program Studi (Prodi) PIAUD Di STIT NU al-Farabi Pangandaran," Jurnal Pendidikan Islam Al-Ilmi 1, no. 1 (May 31, 2018), https://doi.org/10.32529/al-ilmi.v1i1.336. 
ini sangat penting dalam menjaga dan mengembangkan lembaga pendidikan PIAUD maupun mereka yang berkecimpung di dalamnya.Atas dasar inilah kajian PIAUD dan Hadis menjadi penting dilakukan.

\section{Metodologi}

Kajian dalam artikel ini merupakan data-data kualitatif yang diambil dari beragam data dokumen dan pengamatan mendalam.Kehadiran data lewat pengamatan mendalam penting dalam menjadikan kualitas data menjadi baik. Untuk melengkapi data obeservasi dengan melihat fakta dalam proses pembelajaran yang dialami oleh siswa dan siswi PIAUD dan dilakukan oleh beragam guru juga dilakukan wawancara atas beragam key person untuk menjadikan kajian lebih menarik dan mendalam. Mereka ini antara lain lain pihak-pihak yang menjadi pengajar di PIAUD dan ketua pengelolanya. Selain itu, data dapat diperoleh melalui dokumen yang ada dalam pembelajaran di dalamnya dengan melihat dokumen RPS yang dibuat guru.Dengan demikian, data dalam artikel ini merujuk beragam data yang memungkinkan kualitas data lebih baik dengan melibatkan beberapa pihak.

Data hadis dalam kajian ini merujuk pada kajian sebagaimana yang lazim dilakukan ulama hadis.kitab-kitab yang digunakan acuan referensi merupakan kitab yang mu'tabarah yaitu kitab dalam Kutub al-Sittah yang merupakan hirarkhi kitab yang paling baik dalam tradisi Sunni.Setidaknya kesahihan ditunjukkan melalui Kitab Sahih Bukhari dan Sahih Muslim. ${ }^{19}$ Hadis dalam kitab tersebut kemudian dicari model pemahamannya lewat kitab syarah penjelasan di dalamnya yakni tentang PIAUD. ${ }^{20}$ Model kitab syarah merupakan bagian terpenting dalam perjalanan pemahaman yang telah dilakukan oleh Nabi saw. berikut generasi berikutnya sampai ulama abad ke-7 Hijriyah. ${ }^{21}$

${ }^{19}$ A. Elewa, "Authorship Verification of Disputed Hadiths in Sahih Al-Bukhari and Muslim," Digital Scholarship in the Humanities 34, no. 2 (2019): 261-76, https://doi.org/10.1093/llc/fqy036.

${ }^{20}$ Sulaemang L. Sulaemang, "Teknik Interpretasi Hadis Dalam Kitab Syarah Al-Hadis,"

Jurnal Ilmiah Ilmu Ushuluddin 14, no. 2 (March 7, 2016): 125-32, https://doi.org/10.18592/jiu.v14i2.697; Muhammad Alfatih Suryadilaga, Metodologi Syarah Hadis (Yogyakarta: Kalimedia, 2017); Elan Sumarna, "Syarah Hadis Dalam Persfektif Kritik Dakhili Dan Khariji Menuju Pemaknaan Hasdis Yang Integritas," taklim 526 (2016), http:/ /jurnal.upi.edu/taklim/view/4055/syarah-hadis-dalam-persfektif-kritik-dakhili-dankhariji-menuju-pemaknaan-hasdis-yang-integritas-.html.

${ }^{21}$ Agusni Yahya, "Pendekatan Hermeneutika Dalam Pemahaman Hadis: Kajian Kitab Fath al-Bari Karya Ibn Hajar al-Asqalany," Ar-Raniry International Journal of Islamic Studies, Vol. No. 2 Desember 2014, 365-86; Ahmad ibn Ali ibn Hajar Asqalany, al-, Fath Al-Bary Bi Syarb Sahih al-Bukhari (Riyadh: Dar al-Taybah, 2005). 
Model ini kemudian dikembangkan kontekstualisaiskan dalam konteks PIAUD. PIAUD sebagai bagian obyek pendidikan yang spesifik memiliki pemahaman yang spesifik sesuai dengan kapasitas umur mereka. ${ }^{22}$ Sehingga kreativitas dalam hal ini menjadi penting di era kekinian dan di dalam konteks PIAUD. Data yang diperoleh kemudian dilakukan pemahahaman dengan mengunakan model kontekstual dengan melibatkan obyek yang dikaji yaitu PIAUD. Dunia PIAUD dan dunia anak-anak menjadi bagian pembacaan spesifik dalam memahami hadis di dalamnya.Atas dasar inilah kajian hadis dalam PIAUD menjadi penting untuk dilakukan. Kajian ini akan menghasilkan kajian spesifik yang baru di banding kajianyang sudah ada yakni kajian hadis di pesantren, kajian hadis di madrasah, kajian hadis di Perguruan Tinggi atau kajian khas Hadis di Indonesia lainnya.

\section{Hasil Penelitian}

\section{Pendidikan Anak Usia Dini}

Anak usia dini adalah kelompok anak yang berada dalam proses pertumbuhan dan perkembangan yang bersifat unik, dalam arti memiliki pola pertumbuhan dan perkembangan (koordinasi motoric halus dan motoric kasar), intelegensi (daya pikir, daya cipta, kecerdasan emosi dan spiritual), social emosional (sikap dan perilaku serta agama), bahasa dan komunikasi yang khusus sesuai tingkat pertumbuhan dan perkembangan anak. Pendidikan anak usia dini adalah upaya membimbing, mengasuh dan pemberian pembelajaran yang akan menghasilkan kemampuan dan keterampilan pada anak di seluruh aspek kepribadian anak untuk membantu kesiapan anak dalam memasuki pendidikan lanjut (SD).

Adapun tujuan pendidikan anak usia dini antara lain seperti: untuk mempersiapkan anak memasuki pendidikan lebih lanjut, untuk mengurangi angka mengulang kelas, untuk mengurangi angka putus sekolah, untuk mempercepat pencapaian wajib belajar Pendidikan Dasar 9 tahun. Meningkatkan mutu pendidikan, mengurangi angka buta huruf muda, memperbaiki derajat kesehatan dan gizi anak usia dini, dan meningkatkan Indeks Pembangunan Manusia (IPM).

Pendidikan anak usia dini jalur formal diselenggarakan pada Kelompok Bermain (KB) rentang usia 2-4 tahun, Tempat Penitipan Anak (TPA) rentang usia 3 bulan -2 tahun dan Satuan PAUD Sejenis (SPS) rentang usia 4-6 tahun. Sedangkan pendidikan informal diselenggarakan pada pendidikan keluarga yang rentang usianya $0-6$ bulan.

22Lilif Muallifatul Khorida Filasofa, "Analisis Semiotika Pendidikan Moral Anak Usia Dini Dalam Kitab Tarbiyat Al-Aulad Fi Al-Islam,” Sawwa: Jurnal Studi Gender 12, no. 1 (July 6, 2017): 111-26, https://doi.org/10.21580/sa.v12i1.1471. 


\section{Pentingnya Mengajarkan Shalat kepada Anak Usia Dini}

Untuk membentuk karakter pada anak, hendaknya orang tua mengajarakan dan melatih anak untuk melkaukan ibadah semenjak usia dini. Pada usia 5 tahun anak sudah bisa diajarkan bersuci, shalat dan puasa. Fase batita ini merupakan masa-masa penting pada anak (golden age) pada masa ini anak akan mudah menerima dan mengingat informasi apapun, pada masa ini juga anak sangat mudah untuk dilatih. Oleh karena itu, mengajarkan ibadah terutama shalat merupakan kewajiban yang tidak boleh diabaikan oleh orang tua atau guru.

Shalat merupakan amalan yang paling utama diperhitungkan oleh Allah, baik shalatnya maka baik pula amalan yang lainnya. Akan tetapi mengajarkan shalat haruslah diawali dengan contoh orang tua, ketika orang tuanya berwudhu untuk shalat, kemudian menajak anaknya untuk shalat, maka anak akan terbiasa dan anak akan merasa ingi tahu mengerjakan shalat. Begitu juga dengan puasa, pada bulan Ramadhan anak diajak untuk melatih diri untuk melakukan puasa semampunya. Ketika ibadah tersebut sudah biasa dilakukan oleh anak maka otomatis anak sudah tertanam nilai agama yang akan berpengaruh pada moral dan agama anak. ${ }^{23}$

Usia dini merupakan usia emas atau golden age. Pada masa ini anak akan mudah menyerap semua pengetahuan yang didapat pada lingkungan sekitar dengan maksimal. Pada masa ini penanaman nilai-nilai agama haruslah dilakukan secara terus-menerus, sehingga akan menjadi kebiasaan anak. Salah satu pendidikan yang harus diberikan kepada anak yaitu pendidikan agama seperti mengerjakan shalat. Jika orang tua shalat maka anak juga akan ikutshalat tanpa menyadari dan memahami maksudnya. Pemandangan yang berulang-ulang akan membiasakan anak untuk melakukannya. Setelah anak berusia 7 tahun, orang tua harus mendorong dan menyuruhnya shalat. Allah berfirman dalam surah At-Thaha : 20 : 132: "Dan perintabkanlah kepada keluargamu mendirikan shalat dan bersabarlah kamu dalam mengerjakannya.Kami tidak meminta rezeki kepadamu.Dan akibat yang baik itu adalah orang yang bertaqwa". Allah juga berfirman dalam Q.S Luqman : 31 : 17 yang artinya: "Wahai anakeu! Laksanakanlah shalat dan surublah manusia berbuat yang makruf dan cegablah mereka dari yang mungkar dan bersabarlah terhadap apa yang menimpamu, sesungghnya yang demikian itu termasuk perkara yang penting".

Tingkat kepercayan anak pada usia dini ini pemikiran tentang Tuhan sebagai penciptanya yang pada awalnya sebatas pada emosi berubah dengan 2015), 62-64.

${ }^{23}$ Miftahul Achyar Kertamuda, Golden Age, (Jakarta: PT Alex Media Komputindo, 
hubungan dengan menggunakan pikiran dan logika. Mereka telah memahami Tuhan secara lebih realistis. Tahap dimulai pada usia 7-12 tahun, yang mana tahap usia 7 tahun dipandang sebagai permulaan munculnya emampuan berpikir logis, sehingga wajarlah bila anak diberi pelajaran dan dibiasakan melakukan shalat dan dipukul bila melanggarnya. Shalat adalah sebuah amalan yang memiliki tata cara dan bacaan yang harus dilakukan persis seperti yang diajarkan Rasulullah: "surublah anak-anakmu mengerjakan ibadah shalatjika mereka sudah berusia 7 tabun. Dan jika mereka sudah berusia 10 tahun, maka pullah meeka jika tidak melaksanakan shalat dan pisahkeanlah antara mereka ketika mereka tidur." (HR. AlHakim dan Abu Dawud)

Memukul di dalam hadist ini bukan melakukan kekerasan kepada anak tetapi pukulan yang dilkukan kepada anak adalah pukulan kasih sayang. Rasulullah mengajarkan bagaimana cara memukul anak dalam hadist yang diriwayatkan Abu Dawud, "dan janganlah memukul muka atau wajah..."

Di dalam pandangan psikologi, anak usia dini berada pada tahap meniru dalam beragama. Agar anak dapat menerima pengajaran agama dengan baik, orang tua harus menjadi teladan yang baik bagi anak yang dapat mengharapkan kebaikan dari anaknya. Anak-anak akan meniru orang tua jika orang tua menjadi model yang menarik bagi anak-anaknya. Anak usia 7 tahun sudah mulai menganal tanggung jawab dari suatu perbuatan. Mereka sudah memiliki kemampuan membedakan yang benar dan salah berdasarkan berdasarkan peraturan bukan berdasarkan egonya. Oleh karena itu, agama telah dapat diajarkan dalam bentuk kepercayaan yang harus dipatuhi. ${ }^{24}$ Sebagaimana sabda Rasulullah SAW bersabda: "Ajarkanalah shalat pada anak-anak yang berusia 7 tabun dan pukullab ia pada usia 10 tahun lantaran meninggalkan shalat". (HR. Al-Hakim), dan "Setiap kalian adalah pemimpin, dan setiap kalian bertanggung jawab atas orang yang dipmpinnya.Seorang amir (raja) adalah pemimpin, seorang suamipun pemimpin atas keluarganya, dan istri juga pemimpin bagi rumah suaminya dan anak-anaknya. Setiap kalian adalah pemimpin dan kamu sekalian akan diminta pertanggungjawaban atas orangorang yang dipimpinnya"

Adapun bagi anak-anak yang belum mumayyiz atau anak-anak yang memahi perintah shalat, yang masih sekedar ikut-ikutan ketika orang tuanya berdiri, ruku', sujud, dan gerakan shalat lainnya. Sebaiknya orang tua membiarkan anaknya mengikutinya walaupun terkadang si anak tidak menutup auratnya. Namun, apabila anak sudah memasuki usia 10 tahun, maka orang tua wajib memerintahkan anaknya untuk shalat dan jika anaknya meninggalkan shalat makawa wajib bagi orang tua untuk memukul anaknya. Karena shalat merupakan pengalaman realigi, sosiologi, perilaku, didaktis dan historis dalam

${ }^{24}$ Masganti, Psikologi Perkembangan Anak Usia Dini, (Depok: Kencana, 2017), 160-161. 
kehidupan anak.Oleh karena itu, orang tu tidak boleh membiarkannya begitu saja.

Setelah orang tua mengajarkan anaknya tata cara bersuci, wudhu dan shalat, maka tugas orang tua selanjutnya ialah memotivasi anaknya untuk shalat berjamaah di Masjid. Karena Allah memuji hamba-hamba-Nya yang memakmurkan Masjid.Seperti Sabda Allah dalam Al-Quran "Hanya yang memakmurkan Masijd-masjid Allah ialah orangOorang yang berman dikemudian hari, serta tetap mendirikan shalat, menunaikan zakat, dan tidak takut kepada siapapun selain kepada Allah, maka merekalah orang-orangyang dibarapkan termasuk golongan orangorang yang mendapat petunjuk." (At-Taubah : 18).

Rasulullah mendorong uamatnya untuk mengerjakan shalat berjamaah di Masjid seperti sabdanya: "Barang siapa shalat Jamaah dengan ikhlas karena Allah selama empat puluh hari dengan mendapatkan takbir pertama (takbirratul ikram), maka ia dibebaskan dari dua perkara yaitu dibebaskan dari neraka dan kemunafikan". (HR. Tirmizi). Orang tua juga bertanggung jawab menanamkan kepada anaknya untuk melaksanakan shalat Jum'at. Meskipun shalat Jum'at tidak diwajibkan bagi anak-anak, sang ayah tetap wajib membiasakan dan mengajak anak agar shalat Jum'at di Masjid.

\section{Mengajarkan Shalat kepada Anak Usia dini di Tengah-tengah Social Distancing Covid-19}

Hikmah memerintahkan shalat untuk anak usia dini, agar mereka terbiasa melakukannya. Lalu mereka akan mudah melakukannya ketika sudah dewasa. Jika tidak, mereka akan sulit melksankannya karena belum terbiasa sejak kecil. Maka mereka akan merasa berat melaksanakannya. Tiada kekuatan daya dan upaya selain bersama Allah.

Para ulama salaf sangat ulet dalam usaha memerintahkan anak-anak mereka untuk shalat. Ini karena shalat adalah perkara besar, dan tinggi keutamaanya, serta mulia kedudukannya. Abdullah Bin Mas'ud berkata "Jagalah shalat pada anak-anak kalian!" maksudnya harus senantiasa mengingatkan mereka untuk shalat, agar mereka tiada melewatkannya. Dari Hisyam Bin Urwah, ia berkata "ayabku memerintabkan anak-anak untuk shalat jika mereka sudab mengerti, dan puasa jika sudah mampu." Berkata Imam Ibn Atsir "Mereka senang mengajarkan anaknya shalat jika gignya sudah muncul".

Jika shalat merupakan hal yang terpenting dan utama pada tindakan memerintahkan kebaikan, maka juga termasuk ke dalamnya puasa, sedekah, tata krama Islami, dan ketaatan lainnya.Demikian juga jika para wali anak-anak wajib 
untuk memerintah pada kebaikan, maka mereka juga wajib untuk melarang pada kemungkaran. ${ }^{25}$

Menurut John Dewey menyatakan tahapan perkembangan moral anak usia dini berada pada fase konvensional yang memiliki karakteristik sikap dan perilaku anak dilandasi oleh implus biologis dan sosial. Menurut para pakar dapat penulis simpulkan bahwa perkembangan moral dan agama anak usia dini 5-6 tahun adalah suatu kemampuan untuk berinteraksi dengan tingkah laku yang baik sesuai dengan norma-norma, sehingga menimbulkan perilaku baik dan buruk. Seperti contohnya mencium tangan orang tua yang termasuk perilaku terpuji dan sopan.Mencium tangan merupakan suatu penghormatan bagi anak kepada orang yang lebih tua, anak didik kepada gurunya dan istri kepada suaminya. Seperti yang sudah dijelaskan dalam hadist berikut ini:

"Dari Jabir Radhiallahu anhu, bahwa Umar bergegas menuju Rasulullah lalu mencium tangannya" (HR. Ahmad).

Syaikh Muhammad bin Shalih Al-Ustaimin menjelaskan: "Nabi SAW ditanya tentang seseorang yang bertemu saudaranya lalu membungkukkan badan untuknya, beliau menjawab tidak boleh karena membungkukkan badan hanyalah untuk Allah.Adapun mencium tangan ayah, ibu, kakak, syaikh, atau orang alim sebagai penghormatan tidak mengapa”.

Adapun mencium kaki, maka terdapat hadist terkait hal ini: "Dari Safwan bin Assal, bahwa ada dua orang Yahudi bertanya kepada Rasulullah tentang tujuh ayat yang pernah diturunkan kepada Musa AS, setelah dijawab mereka berkata, kami bersaksi bahwa engkau adalah nabi" (HR.Tirmizi, Al-Ibnu Hajar)

Syaikh Al-Mubarakfury berkata: "Hadist tersebut menunjukkan bolehnya mencium tangan dan kaki" Tuhfatul Ahwadzi 7/437.

Hadis-hadis di atas menjelaskan bahwa diperbolehkan mencium tangan sebagai bentuk penghormatan kita kepada orang yang lebih tua.Adapun tujuan dari salaman dan mencium tangan tersebut agar kita memperoleh berkah. Namun sangat disayangkan untuk saat ini, seluruh dunia sedang dilanda dan ditakuti oleh wabah penyakit yang menular yang dengan tanpa sadar dengan mudahnya menyerang tubuh kita melalui percikan-percikan dari hidung atau mulut, batuk atau mengeluarkan nafas pada orang yang terkena wabah yang bernama Coronavirus.

Mengacu pedoman penanganan cepat medis dan kesehatan masyarakat covid-19 DI Indonesia social distancing atau pemabatasan sosial adalah

${ }^{25}$ Muhammad Said, Ahmad Abdurrahman, dkk, Hidup Babagia Hingga Akbir Hayat, (Jakarta Timur: Akbar Media, 2010), 325. 
pembatasan kegiatan tertentu penduduk dalam satu wilayah. Pembatasan sosial dilakukan oleh semua orang dalam satu wilayah.Hal itu disebabkan, virus corona sangat mudah menular.Cara penularannya melalui tetesan kecil yang dikeluarkan dari batuk atau bersin.Pembatasan sosial berkala bertujua untuk mencegah penularan di wilayah tertentu.

Pembatasan secara berskala meliputi meliburkan sekolah dan tempat kerja, pembatasan kegiatan kegamaan, pembatasan kegiatan di tempat umum.Selain itu, masyarakat juga diminta untuk mengurnagi interaksi sosial dan tetap tinggal di rumah maupun pembatasan penggunaan transportasi umum. Social distancing atau physical distancing (pembatasan interaksi fisik), menjadi bagian pencegahan level masyarakat dan individu. ${ }^{26}$

Agar tetap menjadi kebiaasan yang bagus bagi anak, maka orang tua ataupun pendidik menjelaskan kepada anak tentang mencuci tangan sesudah berjabat tangan atau melambaikan tangan saja ataupun mengatupkan kedua tangan di dada sebagai alternatif untuk mencegah penyebaran covid-19. Corona virus adalah suatu kelompok virus yang dapat menyebabkan infeksi saluran pernapasan pada manusia mulai dari batuk, pilek, hingga yang lebih serius seperti Midle East Respiratory Syndrome (MERS) dan Severe Acute Respiratory Syndrome (SARS). Yang mana virus ini baru saja ditemukan pada Desember 2019 lalu di Wuhan Tiongkok. Adapun gejala covid secara umum adalah demam, rasa lelah dan batuk kering.Beberapa pasien mungkin mengalami rasa nyeri dan sakit, hidung tersumbat, pilek, sakit tenggorokan dan diare.

Dalam upaya menangani wabah virus Corona yang semakin luas, pemerintah menganjurkan masyarakat untuk menerapkan social distancing atau pembatasan sosial. Ketika menerapkan social distancing, seseorang tidak diperkenankan untuk berjabat tangan serta menjaga jarak setidaknya 1 meter saat berinteraksi dengan orang lain, terutama dengan orang yang lagi sakit atau beresiko tinggi COVID-19. Ada beberapa contoh social distacing seperti tetap bekerja di rumah, belajar di rumah secara online bagi pelajar, menunda pertemuan atau acara yang dihadiri oleh orang banyak, tidak mengunjungi orang sakit melinkan cukup telepon saja atau video call, dan mengurangi segala aktivitas di luar rumah. Social distancing mungkin akan menghambat segala aktivitas kita. Namun, cara ini cukup efektif untuk mencegah penyebaran virus Corona yang kini sedang mewabah.

Dengan adanya anjuran dari para medis untuk mencegah penyebaran virus corona tersebut, maka warga harus menjaga batasan sosial atau social

26 Aning Jati, http://m.liputan6.com/bola/read/4211246/alasan-social-distancing--saatpandemi-virus-corona.covid-19...diakses pada 26 Maret 2020, 08:10 WIB. 
distancing termasuk orang tua yang memiliki anak-anak usia dini. Selama masa social distancing, orang tua bisa melakukan pendidikan kepada anaknya seperti pendidikan agama dan moral khususnya mengajarkan shalat.Apa itu shalat, bagaimana gerakan shalat, bagaimana tata cara shalat, bagaimana tata cara bersuci, apa saja yang membatalkan wudhu, dan lain sebagainya. Anak usia dini adalah anak yang rentang usianya dari 0-6 tahun, yang mana ia masih berada dalam tahap golden age. Pada masa ini anak-anak akan mengalami kemudahan dan kelancaran dalam memahami ilmu baru yang didapatkannya. Oleh kerena itu, orang tua hendaknya mengajarkan shalat kepada anaknya sejak usia dini agar menjadi sebuah kebiasaannya beribadah ketika ia sudah dewasa kelak.

\section{Pembahasan}

Social distancing umumnya dilakukan dengan penutupan sekolah, penghentian aktifitas kerja diluar layanan penting, isolasi, pembatalan izin keramaian, pembatasan trasportasi umum, hingga penutupan fasilitas rekreasi.Selain itu masyarakat juga dianjurkan menjaga jarak setidaknya 1 meter dari siapapun yang diketahui mengalami gejala batuk dan bersin.Jarak yang terlalu dekat dikhawatirkan bisa menghirup cairan yang mengandung virus. Oleh karena itu penting bagi orang tua untuk mengajarkan kepada anak-anaknya pendidikan agama dan moral berspektif hadis kepada anak di tengah-tengah social distanding. Pendidikan agama dan moral merupakan salah satu pendidikan yang harus diajarkan kepada anak sejak usia dini. Pendidikan agama dan moral anak usia dini berada pada tingkatan yang paling dasar yang dinamakan dengan penalaran moral prakonvensional. Pada tingkatan ini anak belum menunjukkan internalisasi nilai-nilai moral secara kokoh.Maka perlu membiasakan dari orang tua ataupun pendidik yaitu guru untuk berprilaku yang sopan apalagi di tengahtengah masa social distanding.

Prilaku pembiasaan mencium tangan seperti yang dilakukan oleh anak kepada kedua orang tuanya, istri kepada suaminya, murid kepada gurunya, santri kepada kiainya, dan anak muda kepada orang yang lebih tua.Itu semua tidak boleh di lakukan di masa social distancing ini karena dikhawatirkan dapat menularkan virus covid 19.Maka sebagai orang tua ataupun pendidik harus menjelaskan kepada anak-anaknya tentang pentingnya menjaga etika yang baik di masa social distancing ini dikarenakan virus covid 19. Agar tetap membiasan pendidikan agama dan moral kepada anak maka berjabat tangan ataupun mencium tangan orang yang lebih tua dengan tujuan penghormatan dapat dilakukan alternatif lain dengan cara melambaikan tangan, mengatupkan kedua tangan di dada. Maka dengan alternatif tersebut pembiasaan pendidikan agama moral anak masih dapat dilakukan tanpa takut anak bisa tertular virus covid 19.

Selain dengan alternatif lain dengan cara melambaikan tangan atau dengan mengatupkan kedua tangan. Pembiasakan cuci tangan sejak dini dengan 
tujuan menjaga kebersihan juga bisa menjadi bentuk pendidikan agama bagi anak.Didalam agama Islam kebersihan itu sebagian dari iman. Menjaga kebersihan merupakan salah satu cara yang paling efektif dan sederhana untuk mencegah penularan virus corona dengan mencuci tangan. Kebersihan dalam Islam memiliki kedudukan yang sangat penting.Kitab-kitab fiqih ibadah dalam Islam diawali dengan pembahasan thaharah yang mengandung makna kesucian atau kebersihan.

Kebersihan merupakan asas terwujudnya kesehatan, salah satu nikmat terbesar dari Allah yang dianugerahkan kepada manusia, sebagaimana hadis shahih yang dijelaskan berikut ini:

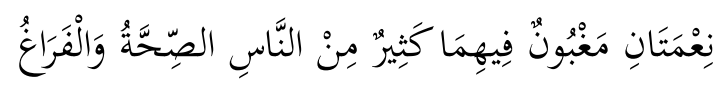

"Ada dua nikmat yang manusia sering dilalaikan (rugi) didalamnya yaitu sebat dan waktu luang (kesehatan)." (HR. Al-Bukhari dan Ahmad)

Dari penjelasan hadis diatas menjelaskan akan nikmat yang diberikan kepada manusia yaitu dengan kesehatan. Kebersihan merupakan asas terwujudnya kesehatan, karena akan pentingnya kebersihan agama Islam memposisikannya sebagai separuh dari iman. Artinya, tuntutan iman adalah menjaga kebersihan. Dengan menjaga kebersihan merupakan salah satu cara yang paling efektif dan sederhana untuk mengajarkan anak-anak akan pendidikan agama, karena agama Islam memposisikan separuh dari iman yang artinya, tuntutan iman adalah menjaga kebersihan. Dan mengajarkan kebersihan sejak usia dini bisa mencegah penularan virus corona atau yang sering disebut dengan COVID-19 di kelurga maupun masyarakat yang berada di sekitar kita. Melakukan caramenjaga kebersihan diri sebenarnya tidak sulit. Bahkan, cara ini juga bisa dikenalkan dan diajarkan kepada anak-anak sejak usia dini.

Dalam mengajaran shalat pada anak usia dini, orang tua atau pendidik perlu melakukan beberapa metode berikut ini, seperti:

\section{Keteladanan}

Keteladanan merupakan sebuah metode pendidikan Islam yang sangat efektif yang sangat diterapkan oleh orang tua atau pendidik dalam proses pendidikan. Karena dengan adanya keteladanan akan mempengaruhi anak pada kebiasaan, tingkah laku dan sikap. Salah satu sifat dari anak usia dini adalah meniru. Dia selalu meniru apa yang dilihatnya. ${ }^{27}$ Dalam kehidupan sehari-hari dapat kita saksikan tindakan keagamaan yang dilakukan anak-anak pada dasarnya mereka peroleh dari meniru.Shalat, berdoa, bersedekah yang mereka

${ }^{27}$ Muhammad Zein, Metodologi Pengajaran Agama, (Yogyakarta: AK Group,1995), 224. 
laksanakan itu merupakan hasil dari melihat perbuatan di lingkungan sekitarnya, baik dari pembiasaan atau pengajaran yang intensif.Seperti mengajak anak ke masjid ketika shalat sebagai contohnya, terutama orang tua melakukannya bersama anaknya.

\section{Pembiasaan}

Metode pembiasaan merupakan kegiatan yang dilakukan secara teratur dan berkesinambungan untuk melatih anak agar memiliki kebiasaan-kebiasaan tertentu, untuk membentuk kepribadian anak seperti emosi, disiplin, budi pekerti, kemandirian, penyesuaian diri bahkan dalam Bergama. Oleh karena itu, biasakanlah anak untuk melaksanakan shalat lima waktu sehari semalam. Dan suatu ketika jika anak tidak melaksanakan shalat, maka ia akan merasakan ada sesuatu yang kurang dalam kegiatan sehari-harinya seperti biasanya. Karena shalat sudah menjadi kebiasaannya.

\section{Nasihat}

Di dalam jiwa manusia terdapat pembawaan untuk terpengaruhi oleh kata-kata yang didengarnya. ${ }^{28}$ Nasihat yang baik adalah nasihat yang sesuai dengan perkembangan jiwa anak, dan dengan kata-kata yang bagus didengar oleh anak, sehingga apa yang didengar oleh anak tersebut masuk kedalam jiwa anak, dan anak tergerak untuk mengamalkannya. Misalnya misalnya nasihat untuk mengamalkan shalat, melaksanakan amal ma'ruf nahi mungkar, dan lain sebagainya. Nasihat juga bias dilakukan dengan menggunakan dongeng, cerita rakyat, yang mengandung nilai moral agamanya.

\section{Perhatian dan Pemantauan}

Selama anak melakukan kegiatan atau aktivitasnya, sebagai orang tua harus memperhatikan dan memantau sejauh mana ia melakukannya dan sejauh mana perkembangannya. Begitu pula dengan shalat, orang tua harus memberikan perhatian dan memantau gerakan dan bacaan shalat anaknya, apakah sudah benar atau belum.Metode perhatian ini juga bisa berupa pujian dan penghargaan. ${ }^{29}$ Dengan demikian, orang tua juga dapat memberikan pujian dan penghargaan kepada anak ketika shalat lima waktu, baik berupa kata-kata pujian ataupun dengan memberikan hadiah kepada anak. Dari sinilah, anak merasa diperhatikan dan dihargai usaha belajarnya menjalankan shalat.

\section{Hukuman}

Bila teladan dan nasihat tidak mampu mendidik anak untuk shalat, maka tindakan tegas harus dilakukan pada saat itu juga sehingga anak akan melaksanakan kewajibannya dan menjadikannya kebiasaan dimasa yang akan

\footnotetext{
${ }^{28}$ Muhammad Qutb, Sistem Pendidikan Islam, (Bandung: Al-Ma'rif, 1984), 334.

${ }^{29}$ Heri Jauhari Mukhtar, Fiki Pendidikan, (Bandung: Remaja Rosda Karya, 2005), 21.
} 
datang. Tindakan tegas ini bisa dilakukan dengan hukuman. Hukuman merupakan salah satu syariat dan termasuk juga salah satu cara yang berhasil, yang sesekali perlu dilakukan di dalam proses pendidikan. ${ }^{30}$

\section{Kesimpulan}

Selama pandemi covid-19 ini, pendidikan sangatlah penting bagi anak usia dini terutama pendidikan agama yang menjadi tanggung jawab dari orang tua dan pendidik. Karena karakter anak akan mudah terbentuk, sebab di usia yang masih kecil inilah anak akan dengan mudah merekam segala sesuatu yang baik ataupun yang tidak baik. Dengan menanamkan pendidikan agama dan moral bagi anak berspektif hadis tengah-tengah pandemi covid-19 di Indonesia, merupakan salah satu upaya agar anak memiliki sikap moral serta akhlak sejak usia dini.

Peran orang tua dalam mengajarkan shalat pada anak-anaknya adalah dengan ikut serta dalam proses pendidikan, menjadi teladan, membiasakan shalat bersama anak, memberikan nasihat yang baik kepada anak, memberikan perhatian dan pemantauan kepada anak, sertamemberikan hukuman yang mendidik kepada anak. Orang tua dan pendidik hendaknya memberikan materi pendidikan kepada anaknya seperti pendidikan agama, sosial, jasmani, moral akal dan juga harus komitmen dalam proses pendidikan.

\section{Bibliografi}

Achyar Kertamuda, Miftahul. 2015. Golden Age. Jakarta: PT Alex Media Komputindo.

Adrian, Kevin . Pentingnya Menerapkan Social Distancing Demi Mencegah Covid-19. http://www.aladokter.com.pentingnya diakses pada 1 April 2020.

Ali, Imran, and Omar M.L. Alharbi. "COVID-19: Disease, Management, Treatment, and Social Impact." Science of The Total Environment 728 (August 1, 2020): 138861. https://doi.org/10.1016/j.scitotenv.2020.138861.

Ali, St Nomah. "Problematika Pembelajaran Al-Qur'an Hadis Di Madrasah Tsanawiyah Negeri (MTs.N) 1 Kolaka."Zawiyah: Jumal Pemikiran Islam 4, no. 2 (December 28, 2018): 127-44. https://doi.org/10.31332/zjpi.v4i2.1082.

${ }^{30}$ Muhammad Yusuf Ak-Hasan, Pendidikan anak dalam Islam, Jakarta: Yayasan AlSofwa, 2011), 51. 
Anggraini, Wardah dan Syafrimen Syafil. Pengembangan Nilai-Nilai Moral dan Agama pada Anak Usia Dini. UIN Raden Intan Lampung.

Ataullahjan, Anushka, Zubia Mumtaz, and Helen Vallianatos. "Family Planning, Islam and Sin: Understandings of Moral Actions in Khyber Pakhtunkhwa, Pakistan." Social Science \& Medicine 230 (June 1, 2019): 49_ 56. https://doi.org/10.1016/j.socscimed.2019.03.011.

Aziz, Safrudin. "Pendidikan Spiritual Berbasis Sufistik Bagi Anak Usia Dini Dalam Keluarga." Dialogia 15, no. 1 (June 1, 2017): 131-49. https://doi.org/10.21154/dialogia.v15i1.1188.

"Budhyaty, Arifah, M. Z. Strategi Penanaman Nilai-Nilai Pendidikan Islam (Kajian Terhadap Perintah Shalat Dalam Hadis Riwa," N.D.

Chasanah, Udzlifatul. "Urgensi Pendidikan Hadis Dalam Pembentukan Karakter Anak Usia Dini." Jurnal Living Hadis 2, no. 1 (May 18, 2017): 83-115. https://doi.org/10.14421/livinghadis.2017.1357.

Elewa, A. "Authorship Verification of Disputed Hadiths in Sahih Al-Bukhari and Muslim." Digital Scholarship in the Humanities 34, no. 2 (2019): $261-$ 76. https://doi.org/10.1093/llc/fqy036.

Filasofa, Lilif Muallifatul Khorida. "Analisis Semiotika Pendidikan Moral Anak Usia Dini Dalam Kitab Tarbiyat Al-Aulad Fi Al-Islam." Sanwa: Jurnal Studi Gender 12, no. 1 (July 6, 2017): 111-26. https://doi.org/10.21580/sa.v12i1.1471.

Habibi, Muazar, 2018. Analisis Kebutuban Anak Usia Dini. Yogyakarta: CV Budi Utama.

Hanur, Binti Su'aidah, and Fatimah Fatimah. "Dari Pesantren Untuk PIAUD." Proceedings of Annual Conference for Muslim Scholars, no. Seri 2 (May 14, 2017): 898-908.

Hasan Shalih, Adnan . 1996. Tanggung Jawab Ayah Terbadap Anak Laki-laki. Jakarta: Gema Insani Pers.

Hermawan, Risdianto. "Pengajaran Shalat pada Anak Usia Dini Perspektif Hadis Nabi Muhammad SAW'. Vol. 23, No. 2, Juli-Desember 2018.

Huda, Mohammad Nurul. "Strategi Mengajar Guru Dalam Meningkatkan Sikap Kemandirian Siswa Di PIAUD."Ta'dibi: Jurnal Manajemen Pendidikan Islam 7, no. 1 (September 3, 2018): 49-76.

Jati, Aning. http://m.liputan6.com/bola/read/4211246/alasan-social-distancing-saat-pandemi-virus-corona.covid-19...diakses pada 26 Maret 2020, 08:10 WIB.

Jauhari Mukhtar, Heri . 2005. Fiki Pendidikan. Bandung: Remaja Rosda Karya. 
Jumrah, Jumrah. "Developing an Intensive Course Model in Improving English Language Skills of Students of Early Childhood Islamic Education Department (Piaud)."International Journal of Language Education 1, no. 1 (March 5, 2019): 22-32. https://doi.org/10.26858/ijole.v1i1.7435.

Masganti. 2017. Psikologi Perkembangan Anak Usia Dini. Depok: Kencana.

Mustaqim, Abdul. 2019. Quranic Pparenting. Sleman: Lintang Hyuning Buwana.

Natalina, Desiani. 2019. Komunikasi dalam PAUD. Tasik Malaya: Kasatria Siliwangi.

Qutb, Muhammad. 1984. Sistem Pendidikan Islam. Bandung: Al-Ma'rif.

Said, Muhammad, Ahmad Abdurrahman, dkk. 2010. Hidup Bahagia Hingga Akbir Hayat. Jakarta Timur: Akbar Media.

Samsukadi, Mochamad. "Paradigma Studi Hadis di Dunia Pesantren."Religi: Jurnal Studi Islam 6, no. 1 (April 10, 2015): 46-75.

Sayadi, Wajidi. "Hadis Daif Dan Palsu Dalam Buku Pelajaran Al-Qur'an Hadis Di Madrasah.”Jurnal Analisa Balai Diklat Semarang 19, no. 02 (2012).

Sulaemang, Sulaemang L. "Teknik Interpretasi Hadis Dalam Kitab Syarah AlHadis." Jurnal Ilmiah Ilmu Ushuluddin 14, no. 2 (March 7, 2016): 125-32. https://doi.org/10.18592/jiu.v14i2.697.

Suryadilaga, Muhammad Alfatih. "Dinamika Studi Hadis di PP Hasyim Asy'ari Tebuireng Jombang: Dari Klasikal Hingga Ma'had 'Aly." AL QUDS : Jurnal Studi Alquran dan Hadis 3, no. 2 (November 25, 2019): 119-34. https://doi.org/10.29240/alquds.v3i2.1001.

. "Ragam Studi Hadis Di PTKIN Indonesia Dan Karakteristiknya: Studi Atas Kurikulum IAIN Bukittinggi, IAIN Batusangkar, UIN Sunan Kalijaga, Dan IAIN Jember." JOURNAL OF QUR'AN AND HADITH STUDIES 4, no. 2 (December 20, 2015): 215-47. https://doi.org/10.1548/quhas.v4i2.2394.

World Health Organiation. Pertanyaan Jawaban Terkait Coronavirus. http://www.who.int.

Yahya, Agusni. "Pendekatan Hermeneutika Dalam Pemahaman Hadis: Kajian Kitab Fath al-Bari Karya Ibn Hajar al-Asqalany." Ar-Raniry International Journal of Islamic Studies, Vol.No.2 Desember 2014, 365-86.

Yusuf Ak-Hasan, Muhammad. 2011. Pendidikan anak dalam Islam. Jakarta: Yayasan Al-Sofwa.

Zein, Muhammad.1995.Metodologi Pengajaran Agama.Yogyakarta: AK Group. 
446 | AL QUDS : Jurnal Studi Alquran dan Hadis vol. 4, no 2, 2020

Zumarni, Zailani dan. "Studi Analisis Terhadap Hadis-Hadis dalam Buku Paket Pada Sekolah Negeri dan Madrasah di Kota Pekanbaru." An-Nida' 39, no. 2 (February 5, 2014): 232-48. 